\title{
ANALISIS FEASIBILITY STUDY BALAI PENGEMBANGAN TERNAK SAPI PERAH DAN HIJAUAN MAKANAN TERNAK MENUJU BADAN LAYANAN UMUM DAERAH
}

\author{
FEASIBILITY STUDY ANALYSIS OF DAIRY AND GREEN CATTLE \\ DEVELOPMENT CENTER TOWARDS REGIONAL GENERAL SERVICES \\ AGENCY
}

\author{
Achmad Firman, Muhammad Hasan Hadiana \\ Departemen Sosial Ekonomi Fakultas Peternakan, Universitas Padjadjaran, \\ Jalan Raya Bandung Sumedang Km 21, Jatinango Sumedang \\ Email: achmad.firman@unpad.ac.id \\ (Diterima 12-06-2021; Disetujui 05-07-2021)
}

\begin{abstract}
ABSTRAK
Penelitian ini dilaksanakan di Balai Pengembangan Ternak Sapi Perah dan Hijauan Makan Ternak, Dinas Ketahanan Pangan dan Peternakan Provinsi Jawa Barat. Tujuan dari penelitian ini adalah mengidentifikasi potensi penerimaan dan biaya dari produksi bibit sapi perah dan produksi susu hasil Balai Pengembangan Ternak Sapi Perah dan Hijauan Makanan Ternak, dan mengindentifikasi potensi peluang balai menjadi BLUD dari kemampuan finansial yang dimiliki. Data yang digunakan adalah data sekunder yang berasal dari balai tersebut. Metode analisis yang digunakan dalam penelitian ini adalah metode analisis finansial yang menitikberatkan pada net present value (NPV) dan internal rate of return (IRR) umtuk melihat kelayakan usaha dari balai ini. Hasil penelitian ini menunjukkan kandang sapi perah belum dimanfaatkan secara optimal, tetapi dianalisis ini kapasitas kandang dimanfaatkan secara optimal. Proyeksi biaya investasi dan biaya operasional masing-masing mencapai Rp16,8 milyar dan Rp3 milyar. Proyeksi penerimaan memiliki potensi lebih dari Rp5 milyar pertahunnya. Hasil analisis kelayakan menunjukkan nilai NPV sebesar Rp237 juta dan IRR sebesar12,24\%. Balai Pengembangan Ternak Sapi Perah dan Hijauan Makanan Ternak dapat ditingkatkan statusnya menjadi BLUD berdasarkan kriteria feasibility study.
\end{abstract}

Kata Kunci: Sapi Perah, Biaya, Pendapatan, Studi Kelayakan

\section{ABSTRACT}

This research was carried out at the Center for Dairy Cattle and Forage Animal Feed, the Department of Food Security and Animal Husbandry, West Java Province. The purpose of this study is to identify potential revenues and costs from the production of dairy cow breeds and milk production from the Center for Dairy and Forage Cattle Development, and to identify potential opportunities for centers to become BLUDs based on their financial capabilities. The data used are secondary data from the center. The analysis method used in this research is the method of financial analysis which focuses on the net present value (NPV) and the internal rate of return (IRR) to see the business feasibility of this center. The results of this study indicate that dairy cows have not been used optimally but in this analysis, the capacity of the cowshed is used optimally. The projected investment and operational costs reach Rp. 16.8 billion and Rp. 3 billion, respectively. The projected revenue has a potential of more than IDR 5 billion per year. The results of the feasibility analysis show that the NPV value is IDR 237 million and an IRR of 12.24\%. The Center for Dairy Cattle and Forage Forage can be upgraded to BLUD based on the criteria of the feasibility study.

Keywords: Dairy cattle, Cost, Revenue, Feasibility Study 


\section{PENDAHULUAN}

Sapi perah adalah hewan ternak yang menghasilkan produksi susu sebagai produk utamanya (Firman, 2010; Al Amin dkk., 2017). Ternak sapi perah pertama kali diperkenalkan ke masyarakat Indonesia pada tahun 1880an oleh pemerintahan kolonial Belanda di Pangalengan dan Lembang (Firman, et al., 2018; Mauludin dkk., 2017). Sampai saat ini perkembangan sapi perah telah melebihi dari awal pengenalannya.

Usaha sapi perah telah menjadi usaha pokok sebagian dari masyarkat petani-peternak, khususnya di Pulau Jawa (Firman, et al., 2019). Kebutuhan susu segar dalam negeri yang terus meningkat menjadi salah satu faktor pemicu peningkatan populasi sapi perah di Indonesia. Hal ini juga memicu permintaan akan bibit sapi perah yang terus meningkat, khususnya di Jawa Barat. Oleh karena itu, pemerintah Jawa Barat mendorong terbentuknya balai pembibitan sapi perah tersebut.

Dinas Ketahanan Pangan dan Peternakan adalah salah satu Organisasi Perangkat Daerah di Jawa Barat yang mengemban misi untuk peningkatan produksi pangan, khususnya produksi pangan hewani asal ternak di Jawa Barat. Tugas dan fungsi dari dinas ini selain menghasilkan kebijakan dan regulasi, juga mengimplementasikan dari kebijakan tersebut.

Dalam pelaksaan tugasnya, Dinas Ketahanan Pangan dan Peternakan Provinsi Jawa Barat memiliki perangkat teknis atau yang sering disebut dengan Unit Pelayanan Teknis Daerah (UPTD). Unit ini adalah bagian dari kelembagaan dinas yang memiliki fungsi untuk kegiatan teknis operasional dan penunjang kegiatan dinas. Dinas Ketahanan Pangan dan Peternakan memiliki 10 UPTD yang telah berjalan sejak lama dan dibentuk berdasarkan kebutuhan spesifik. Dengan dibentuknya UPTD tersebut sebagian kegiatan layanan masyarakat telah dapat dilaksanakan oleh UPTD.

Salah satu UPTD yang berperan dalam produksi pembibitan sapi perah dan produksi susu adalah Balai Pengembangan Ternak Sapi Perah dan Hijauan Makanan Ternak (BPT-SP \& HMT) Cikole Lembang. Unit ini berdiri dengan kegiatan utamanya pembibitan dan budidaya sapi perah dan produksi susu sampai dengan sekarang.

Unit Pelayanan Teknis Dinas, Balai Pengembangan Ternak Sapi Perah dan Hijauan Makanan Ternak (BPT-SP \& HMT) Cikole Lembang berdiri tahun 
1952 dengan nama Taman Ternak yang diprakarsai oleh drh. Soedjono Koesoemohardjo berada di bawah Jawatan Kehewanan Priangan Barat yang kegiatan utamanya budidaya ternak sapiperah serta pengembangan komoditi ternak lainnya. Pada tahun 1964 tanggungjawab Balai diserahkan kepada Dinas Peternakan Propinsi DT I Jawa Barat, selanjutnya pada tahun 1983 berubah menjadi UPTD Balai Pembibitan Ternak dan Hijauan Makanan Ternak (BPT-HMT) Cikole Lembang. Pada tahun 1999 berubah kembali menjadi UPTD BPT-HMT Ternak Perah Cikole Lembang dan pada tahun 2002 hingga 2009. Namun, sesuai dengan Peraturan Gubernur No. 113 Tahun 2009 tentang Organisasi dan Tata Kerja UPTD dan Badan di Lingkungan Pemerintah Provinsi Jawa Barat berubah lagi menjadi UPTD Balai Pengembangan Ternak Sapi Perah dan Hijauan Makan Ternak (BPT Sapi Perah dan HMT) Cikole Lembang sampai dengan saat ini.

Urgensi pembentukan balai ini adalah pelayanan pemenuhan kebutuhan bibit sapi perah dan produksi susu di Jawa Barat. Seiring dengan perjalanan waktu, balai ini menjadi salah satu penyumpang pendapatan asli daerah. Pendapatan asli daerah adalah potensi pendapatan yang diperoleh oleh daerah yang bersumber dari sektor ataupun unitunit kerja yang ada di daerah (Oktavina, 2012). Sumbangan yang diberikan balai ke kas daerah Provinsi Jawa Barat berasal dari pelayanan penjualan bibit sapi perah dan produksi susu yang dihasilkannya. Hal inilah yang cukup menarik untuk dikaji terkait dengan peningkatan status balai dari unit daerah yang hanya memberikan pelayanan saja menjadi Badan Layanan Umum Daerah (BLUD) dengan memberikan keleluasaan di dalam pengelolaan keuangan atau cashflow. Badan Layanan Umum Daerah merupakan satuan kerja perangkat daerah yang fungsinya melayani masyarakat serta memiliki potensi mendapatkan imbal balik atas layanan yang diberikan. Badan Layanan Umum Daerah (BLUD) adalah kelembagaan atau unit kerja di Pemerintah yang didirikan untuk melayani masyarakat di dalam penyediaan barang dan/atau jasa yang dijual tanpa mengutamakan mencari keuntungan pada aktivitasnya, serta memiliki prinsip efisiensi dan produktivitas (Liawan, 2018). Lebih lanjut dijelaskan bahwa pengelolaan keuangan Badan Layanan Umum Daerah diberi keleluasaan dan fleksibilitas untuk menerapkan kegiatan bisnis yang sehat 
dalam rangka memajukan kesejahteraan umum dan mencerdaskan kehidupan bangsa.

Oleh karena balai ini mampu menghasilkan produk yang memiliki daya jual, maka balai ini diberi beban untuk menyumbang pendapatan berupa pendapatan asli daerah (PAD). Atas kemampuannya tersebut, penulis tertarik untuk mendalami lebih detail potensi finansial Balai Pengembangan Ternak Sapi Perah dan Hijauan Makanan Ternak dari kegiatan yang dikelolanya.

Berdasarkan kemampuan pengelolaan keuangan tersebut, penulis mengkaitkan kemampuan pengelolaan keuangan tersebut untuk meningkatkan status UPTD menjadi Badan Layanan Umum Daerah (BLUD). Berdasarkan Peraturan Menteri Dalam Negeri No. 79 Tahun 2018 pasal 1 ayat 1 dinyatakan bahwa Badan Layanan Umum Daerah adalah sistem yang diterapkan oleh unit pelaksar'a teknis dinas/badan daerah dalam memberikan pelayanan kepada masyarakat yang mempunyai fleksibilitas dalam pola pengelolaan keuangan sebagai pengecualian dari ketentuan pengelolaan daerah pada umumnya. Atas dasar pengertian tersebut, Balai Pengembangan Ternak Sapi Perah dan Hijauan Makanan Ternak sesuai dengan tupoksinya adalah menyediakan layanan bibit sapi perah dan produksi susu. Selama ini, balai ini berkontribusi terhadap pendapatan daerah. Berdasarkan aturan tersebut dijelaskan juga bahwa kriteria teknis apabila suatu unit daerah akan ditingkatkan menjadi BLUD adalah (1) kinerja pelayanan di bidang tugas dan fungsinya layak dikelola dan ditingkatkan pencapaiannya melalui BLUD, dan (2) kinerja keuangan SKPD atau Unit Kerja yang sehat dltunjukkan oleh tingkat kemampuan pendapatan dari layanan yang cenderung meningkat dan efisien dalam membiayai pengeluaran.

Oleh karena itu, tujuan dari penelitian ini mengidentifikasi potensi penerimaan dan biaya dari produksi bibit sapi perah dan produksi susu hasil Balai Pengembangan Ternak Sapi Perah dan Hijauan Makanan Ternak, dan mengindentifikasi potensi peluang balai menjadi BLUD dari kemampuan finansial yang dimiliki.

\section{METODE PENELITIAN}

Tempat dan Waktu penelitian

Tempat penelitian dilakukan di Balai Pembibitan Ternak dan Hijauan Makanan Ternak (BPT-HMT) Cikole Lembang, Dinas Ketahanan Pangan dan 
Peternakan, Provinsi Jawa Barat. Penelitian dilakukan dari tahun 20182019.

Jenis penelitian yang dilakukan adalah deskriptif kuantitatif, yaitu penelitian yang dilakukan berdasarkan hasil analisis matematika yang hasilnya diuraikan secara deskriptif.

Variabel penelitian ini adalah analisis finansial pada studi kelayakan. Ada dua analisis yang dilakukan yaitu Net Present Value (NPV) dan Internal Rate of Return (IRR).

Data diperoleh dari laporan dan dokumen yang diperoleh secara hardcopy dari Balai Pembibitan Ternak dan Hijauan Makanan Ternak (BPT-HMT) Cikole Lembang, Dinas Ketahanan Pangan dan Peternakan, Provinsi Jawa Barat.

Metode analisis yang digunakan dalam penelitian ini adalah analisis kelayakan finansial sebagai berikut:

\section{a. Net Present Value (NPV)}

NPV merupakan selisih nilai sekarang antara manfaat (benefit) dan biaya (cost) pada tingkat discount rate tertentu. Formulasi untuk memperoleh nilai NPV adalah:

$\mathrm{NPV}=\sum\left(\mathrm{B}_{\mathrm{t}}-\mathrm{C}_{\mathrm{t}}\right) \times 1 / \sum(1+\mathrm{i})^{\mathrm{t}}$

Dimana:
$\mathrm{B}_{\mathrm{t}}=$ manfaat (benefit) tahun ke-t,

$\mathrm{C}_{\mathrm{t}}=$ biaya (cost) tahun ke-t,

$\mathrm{i}=$ tingkat bunga

$\mathrm{t}=$ tahun ke-1,2,3, ., n

Keputusan yang diambil jika nilai NPV lebih besar dari nol (positif) maka proyek tersebut layak untuk dijalankan, dan jika nilai NPV-nya lebih kecil dari nol (negatif) maka proyek tersebut tidak layak untuk dijalankan.

\section{b. Internal Rate of Return (IRR)}

IRR merupakan kriteria investasi yang menunjukkan tingkat kemampuan suatu proyek dalam mengembalikan modal pinajaman. Nilai IRR diperoleh melalui interpolasi dengan formula seperti di bawah ini:

$\mathrm{IRR}=\mathrm{i}_{1}+\left(\left(\sum \mathrm{NPV}^{+}\right) /\left(\left(\sum \mathrm{NPV}^{+}-\sum \mathrm{NPV}^{-}\right)\right)\right.$ $\mathrm{x}\left(\mathrm{i}_{2}-\mathrm{i}_{1}\right)$

Dimana:

$\mathrm{i}_{1}=$ discount factor pada NPV positif

$\mathrm{i}_{2}=$ discount factor pada NPV negatif

Keputusan yang diambil jika nilai IRR suatu proyek lebih besar dari tingkat bunga bank yang berlaku, maka proyek tersebut layak dijalankan. 
HASIL DAN PEMBAHASAN

Gambaran Umum Balai
Pengembangan Ternak Sapi Perah dan
Hijauan Makan Ternak

Balai Pengembangan Ternak Sapi Perah dan Hijauan Makanan Ternak (BPT-SP \&b HMT) Cikole Lembang berada di Desa Cikole Kecamatan Lembang Kabupaten Bandung yang memiliki jarak $22 \mathrm{Km}$ di sebelah Utara Kota Bandung, $4 \mathrm{Km}$ dari Ibukota Kecamatan Lembang. Memiliki ketinggian $1.200 \mathrm{~m}$ di atas permukaan laut dengan jenis tanah andosol. Berdasarkan kondisi geografis dan topografinya, merupakan dataran tinggi dan beriklim dingin hingga sedang dengan data klimatologis, sebagaimana berikut:

- Temperatur max : $24,6 \mathrm{C}$

- Temparatur min : $13,8 \mathrm{C}$

- Kelembaban : $80,5 \%$

- Curah hujan : $2,393 \mathrm{~mm} / \mathrm{tahun}$

- Evaporasi : $3,4 \mathrm{~mm} / \mathrm{hari}$

- Radiasi : $285 \mathrm{cal} / \mathrm{cm}$

Berdasarkan data agroklimat tersebut, wilayah tersebut sangat cocok untuk pengembangan sapi perah. Oleh karena itu, penempatan lokasi UPTD BPT Sapi Perah telah sesuai dengan agroklimat sapi perah.

Berdasarkan Dinas Peternakan Jawa Barat (2019), Balai Pengembangan
Ternak Sapi Perah dan Hijauan Makanan Ternak Cikole, berlokasi di Kec. Lembang, Kab. Bandung Barat dengan luasan areal 9,885 ha, yang dimanfaatkan untuk areal kebun rumput, kandang sapi, perkantoran, bangunan pengolahan air susu, perumahan pegawai serta tempat pelatihan lapangan. UPTD BPT Sapi Perah dan Hijauan Makanan Ternak Cikole memiliki Instalasi (Sub Unit Pelayanan) Pengembangan Ternak dan Hijauan Makanan Ternak yang berlokasi di Kecamatan Jalancagak Kabupaten Subang yaitu di Desa Bunihayu seluas 8,166 hektar yang saat ini lahannya dimanfaatkan untuk areal kebun rumput, bangunan kantor, perkandangan, gudang pakan, dan sarana penunjang teknis lainnya, serta lokasi yang berada di Kecamatan Sagalaherang yaitu di Desa Sukamandi 10,678 hektar dan di desa Dayeuhkolot seluas 9,063 ha.

\section{Perkembangan Populasi Sapi}

Basis data yang digunakan dalam menentukan perkembangan populasi sapi perah yang ada di Balai Pengembangan Ternak Sapi Perah dan Hijauan Makanan Ternak data populasi tahun 2018. Selanjutnya, data tersebut diproyeksikan selama 20 tahun, yaitu tahun 2018-2037 untuk melihat perkembangan 
populasinya. Penetuan jumlah populasi sapi perah tersebut disesuaikan dengan jumlah kapasitas kandang maksimum yang dapat ditampung pada kandang induk, dara dan anak yang telah tersedia. Adapun perkembangan populasinya dapat dilihat pada Gambar 1.

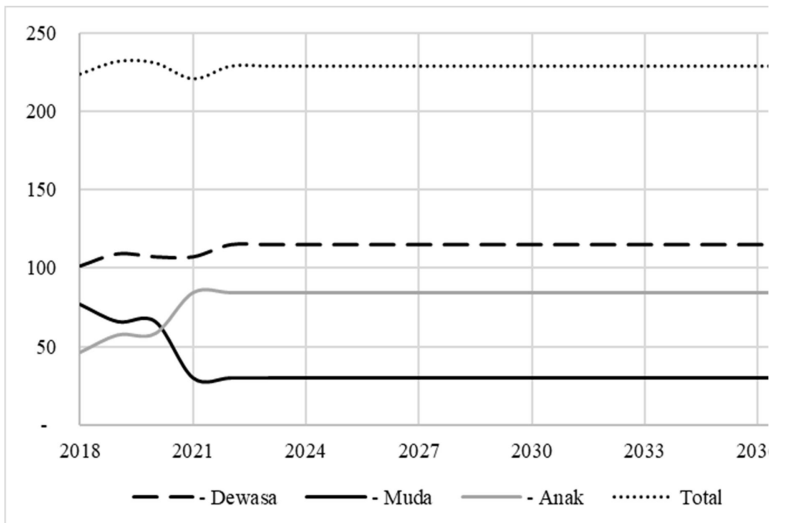

Gambar 1. Proyeksi Perkembangan Populasi Sapi Perah di Balai Pengembangan Ternak Sapi Perah dan Hijauan Makanan Ternak selama 20 tahun (2018-2037)

Berdasarkan Gambar 1 tersebut, total populasi sapi perah induk yang dapat ditampung dan dipertahankan sebagai "pabrik" susu bagi balai adalah 115 ekor sapi, diikuti oleh sapi perah dara sebanyak 30 ekor, dan pedet sebanyak 84 ekor. Kelebihan kapasitas terhadap populasi tersebut, baik itu sapi perah induk, dara, ataupun anak dapat dijual.

\section{Proyeksi Biaya}

Biaya yang dihitung terdiri atas biaya investasi dan biaya operasi. Biaya investasi yang dihitung adalah seluruh aset yang dimiliki balai yang terdiri atas bangunan kantor, gudang, mess, kandang, tempat cooling unit, pengolahan limbah, peralatan dan mesin, kendaraan, serta lahan-lahan hijauan. Total aset balai diperkiraan lebih dari 16,8 milyar. Adapun biaya operasi dan produksi menjadi biaya operasional yang rata-rata setiap tahunnya menghabiskan lebih dari Rp3 milyar (Gambar 2). Biaya produksi digunakan untuk membiayai proses produksi, sedangkan biaya operasi digunakan untuk biaya manajemen dan administrasi.

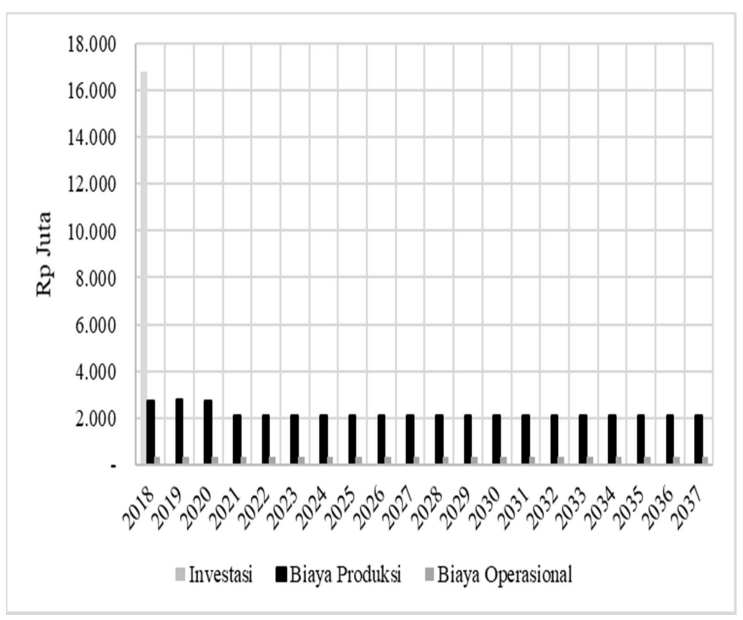

Gambar 2. Proyeksi Biaya Investasi dan Operasi Balai Pengembangan Ternak Sapi Perah dan Hijauan Makanan Ternak selama 20 Tahun

\section{Proyeksi Penerimaan}

Penerimaan dari balai diperoleh dari penjualan produksi susu, penjualan sapi dara, dan penjualan pedet. Harga susu yang dijual di balai adalah sebesar Rp6.000 per liter. Adapun penjualan sapi 
perah induk adalah Rp20 juta/ekor, penjualan sapi perah dara adalah Rp15 juta/ekor, dan penjualan pedet, baik jantan ataupun betina sebesar Rp5 juta/ekor. Di samping itu, kontribusi PAD yang dihasilkan oleh balai diproyeksikan sebagai penerimaan total yang diterima oleh balai. Dengan asumsi harga tersebut maka dapat diproyeksikan penerimaan selama 20 seperti pada Gambar 3.

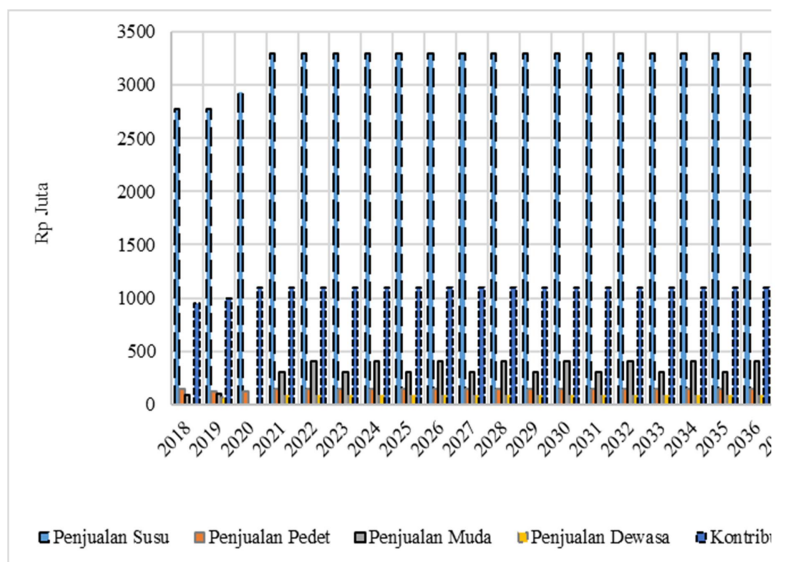

Gambar 3. Proyeksi Penerimaan Balai

Pengembangan Ternak Sapi Perah dan Hijauan Makanan Ternak selama 20 Tahun

\section{Analisis Kelayakan Finansial}

Penghitungan analisis finansial menggunakan asumsi diskonto (discount rate) sebesar $12 \%$. Asumsi ini digunakan dengan tingkat suku bunga pasar yang berlaku sekarang ini sebesar 12\%. Oleh karena itu, seluruh penerimaan dan biaya harus dikonversikan terlebih dahulu ke discount factor sebesar $12 \%$ selama 20 tahun.
Ada dua analisis finansial yang digunakan didalam mengukur tingkat kelayanan usaha, yaitu net present value (NPV) dan internal rate of return. Hal ini sesuai dengan Peraturan Menteri PPN/Bappenas No. 4 Tahun 2015 tentang Tatacara Pelaksanaan Kerjasama Pemerintah Dengan Badanusaha Dalam Penyediaan Infrastruktur sebagai dasar analisisnya.

Hasil analisis kelayakan finansial yang dilakukan berdasarkan hasil proyeksi biaya dan penerimaan selama 20 tahun dapat dilihat pada Tabel 1.

Tabel 1. Hasil Analisis Kelayakan Finansial

\begin{tabular}{ccl}
\hline $\begin{array}{c}\text { Kriteria } \\
\text { Kelayakan }\end{array}$ & \multicolumn{1}{c}{ Hasil } & $\begin{array}{c}\text { Tingkat } \\
\text { Kelayakan }\end{array}$ \\
\hline NPV $(\mathrm{Rp})$ & 237.212 .793 & $\begin{array}{l}\text { NPV }>1 \\
\text { IRR }>\text { Tingkat } \\
\text { Bunga Pasar }\end{array}$ \\
IRR $(\%)$ & 12,24 & \begin{tabular}{l} 
Bung \\
\hline
\end{tabular}
\end{tabular}

Berdasarkan Tabel 1 tersebut dapat dikatakan bahwa kriteria penilaian kelayakan usaha nilai NPV menghasilkan Rp237 juta dan nilai IRR adalah 12,24\%. Hasil tersebut mengindikasikan bahwa nilai NPV $>1$ menunjukkan bahwa proyek dapat dikatakan layak (Afiyah dkk., 2015). Adapun nilai IRR menunjukkan angka 12,24\%. Nilai ini lebih besar dari tingkat Weighted Average Cost of Capital (WACC) sebesar 10,08\% (Yasuha dan Saifi, 2017). 


\section{Potensi Perubahan Balai Pengembangan Ternak Sapi Perah dan Hijauan Makanan Ternak Menuju Badan Layanan Umum Daerah}

Berdasarkan hasil analisis feasibilty study menunjukkan bahwa kemampuan pengelolaan keuangan oleh balai telah mampu secara mandiri untuk menghidupi operasi dari usaha pembibitan sapi perah dan produksi susu. Kemampuan inilah dapat dijadikan salah satu indikator bahwa Balai Pengembangan Ternak Sapi Perah dan Hijauan Makanan Ternak layak untuk ditingkatkan statusnya menjadi Badan Layanan Umum Daerah. Oleh karena itu, atas indikasi ini pihak pengelola balai dapat melakukan kajian mendalam persiapan menunju BLUD karena ada beberapa persyaratan lainnya yang diperlukan untuk mengubah status menjadi BLUD.

\section{KESIMPULAN DAN SARAN}

Kesimpulan yang dapat dari hasil penelitian ini adalah (1) Kandang sapi perah belum dimanfaatkan secara optimal tetapi pada analisis ini kapasitas kandang dimanfaatkan secara optimal,

Proyeksi biaya investasi dan biaya operasional masing-masing mencapai Rp16,8 milyar dan Rp3 milyar, (3) Proyeksi penerimaan memiliki potensi lebih dari Rp5 milyar pertahunnya, (4)
Hasil analisis kelayakan menunjukkan nilai NPV sebesar Rp237 juta dan IRR sebesar 12,24\%, dan (5) Balai Pengembangan Ternak Sapi Perah dan Hijauan Makanan Ternak dapat ditingkatkan statusnya menjadi BLUD berdasarkan kriteria feasibility study.

Saran yang dapat diberikan adalah sebaiknya pihak Dinas Ketahanan Pangan dan Peternakan, Provinsi Jawa Barat sebagai induk dari balai ini untuk melakukan studi lebih lanjut terkait dengan rekomendasi penelitian yang dihasilkan. Ada beberapa prasyarat lainnya yang harus dipenuhi saat balai akan berubah menjadi Badan Layanan Umum Daerah.

\section{DAFTAR PUSTAKA}

Afiyah A, Saifi M, dan Dwiatmanto. (2015). Analisis Studi Kelayakan Usaha Pendirian Home Industry. Jurnal Administrasi Bisnis, |Vol. 23(1): 1-11.

Al Amin A.F, Hartono M, dan Suharyati S. (2017). Faktor-Faktor Yang Memengaruhicalvingintervalsapi Perahpada Peternakan Rakyatdi Beberapa Kabupaten/Kotaprovinsi Lampung. Jurnal Penelitian Peternakan Indonesia, Vol. 1(1): 33-36.

Dinas Peternakan Provinsi Jawa Barat. 2019. Laporan Tahunan Dinas Peternakan Provinsi Jawa Barat Tahun 2018. Dinas Peternakan Provinsi Jawa Barat. Bandung 
Firman A. (2010). Agribisnis Sapi Perah Dari Hulu Sampai Hilir. PT. Widya Padjadjaran.

Firman A, Budimulati L, Paturochman M and Munandar M. (2018). Succession models on smallholder dairy farms in Indonesia. Livestock Research for Rural Development. Volume 30, Article \#176.

Liawan C. (2018). Analisis Penggunaan dana Badan Layanan Umum Daerah (BLUD) Pada Rumah Sakit Umum

Daerah Sele Be Solu Kota Sorong. Jurnal Pitis AKP, Vol. 2(1): 1-12.

Mauludin M.A, Alim S, dan Sari V.P. (2017). Pengembangan Dan Dinamika Moda Produksi Usaha Peternakan Sapi Perah Di Pangalengan Jawa Barat. Jurnal Sosiohumaniora, Vol. 19(1): 37-44.
Oktavina D. (2012). Analisis Pendapatan Asli Daerah Dan Faktor-Faktor Yang Mempengaruhinya Dalam Rangka Otonomi Daerah : Pendekatan Error Correction Model. Jurnal Ekonomi Pembangunan, Vol. 10(2): 88-100.

Tanujaya C. (2017). Perancangan Standart Operational Procedure Produksi Pada Perusahaan Coffeein. Jurnal Performa, Vol. 2(1): 90-95.

Yasuha J.X.L dan Saifi M. (2017). Analisis Kelayakan Investasi Atas Rencana Penambahan Aktiva Tetap. Jurnal Administrasi Bisnis Vol. 46(1): 113-121. 